\title{
FOURTEENTH AMENDMENT ENFORCEMENT AND CONGRESSIONAL POWER TO ABOLISH THE STATES
}

During the October 1965 Term, the United States Supreme Court decided two cases, United States v. Guest ${ }^{1}$ and Katzenbach v. Morgan, ${ }^{2}$ which have potentially revolutionary implications for the future of federalism. These two cases concerned the extent of congressional power to enforce the provisions of the fourteenth amendment. ${ }^{3}$ The expansion of congressional authority which they announce could result in the establislment of an entirely new balance of power between the state and national governments.

In 1883, after the nation had tired of reconstructing the states which had rebelled thirty years earher, the Supreme Court returned its decision in the Civil Rights Cases. ${ }^{4}$ That decision severely limited the potential scope of legislative power under the fourteenth amendment. This result was accomplished in two ways. First, the Court reserved for itself the power to specify the kinds of activities which were forbidden by the equal protection or due process clause. ${ }^{5}$ Congressional deliberations on that issue were not taken into account. Second, the Court limited Congress's fourteenth amendment power by the doctrine of state action. Federal legislative power could not be applied to activities which interfered with the

1383 U.S. 745 (1966).

2384 U.S. 641 (1966).

3 The pertinent provisions of the fourteenth amendment read as follows: "Section 1 . All persons born or naturalized in the United States, and subject to the jurisdiction thereof, are citizens of the Umited States and of the State wherein they reside. No State shall make or enforce any law which shall abridge the privileges or immunities of citizens of the United States; nor shall any State deprive any person of life, liberty, or property without due process of law; nor deny to any person within its jurisdiction the equal protection of the laws. ...

"Section 5. The Congress shall have power to enforce, by appropriate legislation, the provisions of this article."

4109 U.S. 3 (1883).

5See, e.g., Civil Right Cases, supra note 4 at 15 ; Ex parte Virginia, 100 U.S. 339 (1879); Strauder v. West Virginia, 100 U.S. 303 (1879). The privileges and immunities clause of the fourteenth amendment was limited by the Supreme Court in the Slaughter House Cases, 83 U.S. (16 Wall.) 36 (1873). The Court distinguished privileges and immunities inherent in federal citizenship from those incidental to state citizenship. The former were considered few in number, and the fourteenth amendment's privileges and immunities clause applied only to them. That case has never been questioned by an opimion in which a majority of the Court concurred. The clause has very little vitahty, compared with that enjoyed by the equal protection and due process clauses, and will not be discussed in this Comment. For indications of the possible resurgence of that clause, see Mr. Justice Douglas's concurring opinions in Heart of Atlanta Motel, Inc. v. Umited States, 379 U.S. 241, 279 (1964); Bell v. Maryland, 378 U.S. 226, 242 (1964); and Edwards v. California, 314 U.S. 160, 177 (1941). 
free exercise of fourteenth amendment rights unless the state was in some way associated with the acts. ${ }^{8}$

United States v. Guest, the first of the two decisions returned, concerned the application of the concept of state action to federal enforcement statutes. The Court announced its refusal to imsist upon state association with activities interfering with free exercise of fourteenth amendment rights as a condition precedent to the application of enforcement legislation.

In Katzenbach v. Morgan, the Court adopted a new, more lenient standard of review for use in considering congressional legislation designed to enforce the provisions of the fourteenth amendment. The focus of the Court's consideration shifted from the scope of the constitutional prohibition to the reasonableness of the congressional judgment that the activities proscribed by a statute infringe fourteenth amendment riglits. The Court indicated that it would no longer make its own determination whether the acts proscribed are among those prohibited by the amendment when reviewing enforcement legislation. If Congress's interpretation of the equal protection or due process clause to prohibit the acts condemned by the statute is reasonable, it will be upheld.

Guest and Morgan each considered one of the two questions which arise when the Court construes congressional enforcement powers. Guest was concerned with the definition of the parties to which fourteenth amendment legislation can be applied. Morgan dealt with the problem of determining the content of the rights granted by the equal protection and due process clauses. The two cases announced a substantial expansion of federal powers at the expense of the sphere of influence traditionally thought to be reserved to the states. It is the purpose of this Comment to investigate, first, the extent of that expansion, and second, the limitations imposed upon congressional enforcement powers by the separation of powers within the national government.

THE CONCEPT OF STATE ACTION

- The state action concept, as originally articulated, hmited congressional enforcement power to the adoption of "appropriate legislation for corrrecting the effects of .... prohibited State laws and State acts, and thus to render them effectually null, void, and innocuous." Statutes enacted under the fourteenth amendment had to meet two requirements before they could be sustained. First, they had to be predicated upon some

: ${ }^{\prime}$ 6. Hodges v. United States, 203 U.S. 1, 14 (1906); Civil Rights Cases, 109 U.S. 3, 11 (1883); United States v. Cruikshank, 92. U.S. 542 (1875).

7 Civil Rights Cases, 109 U.S. 3, 11 (1883). 
state association with acts infringing the positive rights secured by the amendment. Second, fourteenth amendment legislation could only prohibit acts which infringed rights-Congress could not impose affirmative obligations. ${ }^{8}$ The Guest case dealt only with the first requirement. An investigation of other civil rights crimes cases will reveal that Guest inerely culminates a trend which has been progressing for twenty-two years. No decisions have considered congressional power to impose affirmative obligations. However, there are indications that the Court will soon admit the existence of that power.

\section{A. History of State Action as a Limitation on Congressional Power}

The interpretation of congressional power to enforce the fourteenth amendment put forth by a majority of the Justices in the Guest case is a very significant, but not sudden, departure froin traditional constitutional doctrine. ${ }^{9}$ After the Civil Rights Cases, congressional enforcement powers were thought to include only the power to react to the adoption of a state law or to action taken by state agents or officials which was adverse to equal protection and due process riglits. The only appropriate congressional reaction was legislation which would nullify the law or action. Moreover, in the case of actions taken by state agents, congressional enactments could not be applied unless the acts complained of were either supported by state authority "in the shape of laws, customs, or judicial or executive proceedings" or were sanctioned by the state..$^{10}$ In other words, the only acts of state agents which federal statutes could penalize under the fourteenth amendment were those (1) which the state itself did not say were crimes or civil wrongs, (2) which in fact invaded the rights described ${ }^{11}$ by the equal protection or due process clause, and (3) which were taken by the agent in his official capacity.

Thus, the state action rule limited the power of Congress to providing penalties for actions taken by a state official. Those actions infringed the

8 Ibid.

0 See, e.g., Hodges v. United States, 203 U.S. 1 (1906); Civil Rights Cases, 109 U.S. 3 (1883); United States v. Cruikshank, 92 U.S. 542 (1875).

10 Civil Rights Cases, 109 U.S. 3, 17 (1883).

11 There are three aspects of a right, all of which might be included in its definition. The first is a description of its content. The second is the imposition of a duty upon some person or agency to refrain from infringing the right. The third is the means by which that duty is enforced-a remedy. For purposes of illustration, reference to the right to freedom of speech, contained in the first anjendment, is helpful. It provides that "Congress shall make no law abridging ... freedonl of speech . . . ." The words "freedonl of speech" are the description of the content of the right. "Congress shall make no law" is the imposition of a duty upon an agency to refrain from infringing the right. As used in this Comment, the term "description" will mean that first aspect of the right-the description of its content. 
rights described by the equal protection or due process clauses if, and only if, under traditional principles of agency law ${ }^{12}$ they could be imputed to the state. There is reason to believe that this interpretation of congressional enforcement powers was adopted in reliance upon the assumption that if a state official exceeded the limits of his authority, the state would either punish him or provide the party whose rights were infringed with a civil remedy. ${ }^{13}$ Later, it became apparent that this assumption was invalid. ${ }^{14}$ Southern juries were not prone to return convictions or civil verdicts against white state agents who had invaded the riglits of Negroes. White prosecutors were loathe to prosecute white officials who, by force, denied Negroes rights which were widely accorded to white citizens. By the time the Court becane aware that the rights described by the equal protection and due process clauses could never be freely exercised by Negroes without substantial intervention by the federal legislative power, it was too late to remove the narrow interpretation put upon that power by the Civil Rights Cases. ${ }^{15}$ Two factors militated against the abandonment of that interpretation, and were sufficiently strong to render such an action unthinkable. ${ }^{16}$ The first was the Court's conception of its role when interpreting the Constitution. For more than fifty years after the decision in the Civil Rights Cases, the Court conceived of itself as announcing immutable primciples whenever it decided a constitutional question. ${ }^{17}$ Second, during the same period, the Court showed a very deep respect for the value of precedent. ${ }^{18}$ During these years, a rather

12 See, e.g., Mecheas, AGency 17-83 (4th ed. 1952).

13 See Civil Rights Cases, 109 U.S. 3, 17-18 (1883); Franz, Congressional Power to Enforce the Fourteenth Amendment Against Private Acts, 73 YaLE L.J. 1353, 1377-81 (1964); Van Alstyne \& Karst, State Action, 14 Stan. L. Rev. 3,5 (1961).

14 See Screws v. United States, 325 U.S. 91 (1944); Crews v. United States, 160 F.2d 746 (5th Cir. 1947); Catlette v. United States, 132 F.2d 902 (4th Cir. 1943).

15109 U.S. 3 (1883). See text accompanying notes 9-12 supra.

${ }^{16}$ It is, of course, recognized that Supreme Court justices, during the period from the civil war to the New Deal, took a very restrictive view of the proper sphere of federal action. Thus, congressional power under the commerce clause was construed stringently. See, e.g., United States v. E.C. Knight Co., 156 U.S. 1 (1895). However, we are not here concerned with the judges' views on states rights. Only their conception of their role as judges is of interest.

17 See Cardozo, The Nature of the Judrctac Process 164 (1921); Llewrerys, The Common LAw Tradition 24-25 (1960). For an indication that this conception is now of little force see Brown v. Board of Education, 347 U.S. 483, 492 (1954). "In approaching this problem [the constitutionality of public school segregation], we cannot turn the clock back to 1868 when the Amendment was adopted, or even to 1896 when Plessy v. Ferguson was written."

18 See Wanabauge, Study or Cases \& 77 (2d ed. 1894); Miller, The Use and Value of Authorities 23 Ax. L. REv. 165 (1889). These two factors together are the principal characteristics of the judicial method which Llewellyn has called the "Formal Style." See LLEWELIYN, BRAMBLE BUSH 56-59 (1960). 
large number of cases had been decided in accord with the Civil Rights Cases. ${ }^{10}$ Overruling the latter would require that the former be overturned. The Court's solution to this dilemma was to "stretch" the concept of state action.

The first step in this "stretching" process was the abrogation of the requirement that, before penalties prescribed by Congress could be applied, there must be a finding that the state did not declare the acts performed by the accused official to be crimes. ${ }^{20}$ In a subsequent case, the Court rescinded the requirement that the questioned acts must not create a civil cause of action. ${ }^{21}$ At the same time, it was held that if state authority was the means by which the official gained the position which enabled him to infringe upon the victim's free exercise of his rights, the state was sufficiently involved in the official's acts to permit a finding of state action..$^{22}$ Finally, it was held that private individuals who conspired with state officials to deprive others of the free exercise of rights described by the due process clause of the fourteenth amendment could be punished under federal legislation if those officials, pursuant to the conspiracy, exercised powers given by the state. ${ }^{23}$

The concept of state action had been expanded to the point that the only instances when congressional enforcement statutes could not be applied to the actions of an individual which interfered with another's equal protection or due process rights were those in which: (1) the individual acted wholly in his private capacity, (2) he exercised no state authority through which he gained the position which enabled him to perform the acts, and (3) he did not act in conspiracy with a state official who had exercised powers conferred upon him by the state to facilitate the alleged infringement of rights. However, there remained sufficient room for the $\mathrm{Ku} \mathrm{Klux} \mathrm{Klan}$ to gather together and terrorize Negroes, and yet remain

19 E.g., Corrigan v. Buckley, 271 U.S. 323 (1926) ; Frank v. Mangum, 237 U.S. 309 (1915); Barney v. City of New York, 193 U.S. 430 (1904); James v. Bowman, 190 U.S. 127 (1903) (fifteenth amendment); Plessy v. Ferguson, 163 U.S. 537 (1896); Logan v. United States, 144 U.S. 263 (1892).

20 Screws v. United States, 325 U.S. 91, 108 (1945) (defendant sheriff claimed his acts constituted murder under state law).

21 Monroe v. Pape, 365 U.S. 167 (1961).

22 Screws v. Umited States, 325 U.S. 91, 107-13 (1945); Crews v. United States, 160 F.2d 746, 749-50 (5th Cir. 1947); Catlette v. United States, 132 F.2d 902, 905-06 (4th Cir. 1943).

23 United States v. Price, 383 U.S. 787, 794 (1966). That Price was announced the sane day as Guest and relied upon a finding of state action should not militate against the conclusions drawn from the Guest opinions of Justices Clark and Brennan. See text accompanying notes 39-50 infra. It is possible that a decision was first reached in the Price case because of the ease with which state action could be found, and that, for the same reason, unanimity was easily achieved. The Guest opinions were perhaps written after agreement had been reached in the Price case. 
immune from federal punishment. The violent acts of white supremacists remained in large part subject only to state justice. In view of the lack of ability or desire on the part of Southern States to arrest, try and punish the murderers of civil rights workers and Negroes, it is hardly surprising that this last segment of private activity would be subjected to federal power. The Guest case bridged the gap.

\section{B. Guest and State Action}

United States v. Guest eliminates state action as a condition precedent to the application of congressional enforcement legislation enacted under the fourteenth amendment. The Court's opinion considered and found valid an indictment returned under the civil rights conspiracy provision contained in section 241 of the federal criminal code. ${ }^{24}$ The district court had dismissed the indictment on the grounds that it failed to charge an offense under the laws of the Umited States. ${ }^{25}$

The indictment charged that the defendants had conspired to deprive Negro citizens of (1) the right to equal enjoyment of facilities of public accommodation, (2) the right to equal utitization of public facilities, (3) the right to equal use of public streets and highways in the vicinity of Athens, Georgia, (4) the right to travel freely upon interstate transportation facilities in Georgia, and (5) other rights exercised by white citizens in the vicimity of Athens, Georgia. ${ }^{26}$ The means by which the defendants were alleged to have effectuated the ends of the conspiracy were: (1) shooting, beating, and killing Negroes, (2) destroying property belonging to Negroes, (3) verbal and physical threats to the person and property of Negroes, (4) going in disgmise on the highways and the premises of others and burning crosses at night in public view, and (5) causing the arrest of Negroes by means of false reports that they had committed criminal acts. ${ }^{27}$ The only fact in the record before the Supreme Court was the statement by the district court that it was com-

2418 U.S.C. $\$ 241$ (1948). "If two or more persons conspire to injure, oppress, threaten, or intimidate any citizen in the free exercise or enjoyment of any right or privilege secured to him by the Constitution or laws of the United States, or because of his having so exercised the same; or

"If two or more persons go in disguise on the highway, or on the premises of another, with intent to prevent or hinder his free exercise or enjoyment of any right or privilege so securedboth."

"They shall be fined not more than $\$ 5,000$ or imprisoned not more than ten years, or

25 United States v. Guest, 246 F. Supp. 475 (M.D. Ga. 1964).

26 United States v. Guest, 383 U.S. 745, 747-48 n.1 (1966).

27 Ibid. 
mon knowledge that two of the defendants recently had been acquitted by a jury in a state prosecution for the murder of Lemuel A. Penn. ${ }^{28}$

The paragraphs of the indictment under which the Court discussed the applicability of section 241 were the second, third, and fourth. ${ }^{29}$ Those paragraphs charged conspiracy to infringe the rights of Negroes freely to use the facilities and instrumentalities of interstate commerce within the State of Georgia and their rights to equal utilization of public facilities.

Justice Stewart, writing for the Court, briefly considered the allegation that the defendants conspired to infringe the rights of Negroes to travel on or in interstate facilities. He simply noted that the rule was well settled that the right to travel freely between and within the state is constitutionally protected, and that it has long been held that this right is among those protected by the statute upon which the indictment was based. ${ }^{30}$

The allegation that the defendants conspired to infringe the rights of Negroes to the equal use of public facilities was not so easily dispatched. Since that right arises under the equal protection clause of the fourteenth amendment, section 241 had to be considered as fourteenth amendment legislation for this aspect of the case. The traditional interpretation of the applicability of sucl statutes required the Court to find in the indictment an allegation which would support proof of state involvement in the alleged deprivation of riglits. ${ }^{31}$ The Court found such an allegation in the assertion that the defendants intended to achieve the ends of their conspiracy by "causing the arrest of Negroes by means of false reports that

28 Ibid. Lt. Col. Penn, a Negro army reserve officer, was shot while driving through Georgia enroute to Washington, D.C. after a military assignment.

29 The objection which the district court raised to the first paragraph of the indictment was a pleading point: The government failed to allege that the defendants were motivated by racial discrimination in their conspiracy to deny Negro citizens the right to equal enjoyment of public accommodations. That right is totally dependent upon $\S 201$ (a) of the Civil Rights Act of 1964, 78 Stat. 241 (1964), 42 U.S.C. $\S 2000 \mathrm{a}$ (a) (1964); since it is defined in that section as the right to be free from discrimination on the basis of race, the omission of an allegation of racially discriminatory motivation was fatal. United States v. Guest, 246 F. Supp. 475, 484 (M.D. Ga. 1964). The Supreme Court refused to review this reasoning, relying on the established principle that an appeal cannot be had when the judgment rests upon pleading deficiencies in an indictment. United States v. Guest, 383 U.S. $745,751-52$ (1966). The issue raised by the fifth paragraph of the indictment was not pressed on appeal. $I d$. at 749 n.2.

30 The Court did not find it necessary to state the constitutional basis for the right to travel. It was sufficient to say that the right is constitutionally protected independent of the fourteenth amendinent. This holding relieved the Court from the necessity of dealing with the state action problem, with respect to this aspect of the indictment. It is only when violations of fourteenth amendinent rights are charged that traditional doctrine requires an allegation of state association with the asserted wrong. 383 U.S. at 758-60.

${ }^{31}$ See text accompanying notes 7-23 supra. 
such Negroes had committed criminal acts."32 This allegation was construed to be sufficient to support proof of cooperation of state agents in the making of the false reports, which would be sufficient proof of state involvement. ${ }^{33}$

In its application to the equal use of public facilities, the Court's interpretation of section 241 caused dispute among the Justices. Justice Stewart construed the statute as incorporating only the "bare terms" of the equal protection clause and thus requiring an allegation of state involvement in the conspiracy. ${ }^{34} \mathrm{He}$ stated that he intended only to interpret section 241 and expressly disclaimed intent to rule on the extent of congressional enforcement power. ${ }^{35} \mathrm{He}$ said that equal protection rights arise "only when there has been involvement of the state or of one acting under the color of its authority." ${ }^{\text {"36 }}$ Although a literal reading of the statute makes it applicable to all conspiracies regardless of the state's involvement, ${ }^{37}$ Justice Stewart chose to read the statute in terms of a more narrow state action requirement. Three reasons can be suggested for the limitation the Court placed on the scope of its decision. First, the Court may have felt that in the instant case no broader application of the statute was needed, since state action could be found. Second, the Court may have reasoned that Congress enacted the statute with traditional constitutional doctrine in mind, so that in spite of the broad language, it was not intended to have broader reach than the amendment itself. ${ }^{38}$ Third, the Court may have felt that Congress's power under the fourteenth amendment did not extend to private acts, so that the statute could be saved only by the more narrow reading. If this was the Court's rationale, the concurring opinions of Justices Brennan and Clark are in sharp conflict with Justice Stewart's.

Justice Brennan, in his concurring opinion ${ }^{30}$ which was joined by the

32383 U.S. at $756-57$.

33 Ibid.

34 Id. at 754-55.

35 "[N] othing said in this opinion goes to the question of what kinds of other and broader legislation Congress might constitutionally enact under $\S 5$ of the Fourteenth Amendment to implement [the equal protection] ... Clause or any other provision of the Amendment." Id. at 755.

36 Ibid.

37 See note 24 supra.

38 Section 241 was originally part of the Civil Rights Act of 1866. Since the fourteenth amendment was not adopted until 1868 and the state action concept was not fully articulated until 1883, it is not possible that the statute was drafted with the state action himitation in mind. However, section 241 bas been re-enacted several times since the Supreme Court decided the Civil Rights Cases. Upon each re-enactment of the section, Congress has been silent about its intended scope of applicability. Congress's mere silence on this matter could indicate congressional acquiescence in the state action limitation and thus Congress's intent that the section have no greater application than that allowed by the doctrine.

39383 U.S. at 774. 
Chief Justice and Justice Douglas, dissented from the Court's restrictive construction of section 241 . He said that the statute reached purely private conspiracies. ${ }^{40} \mathrm{He}$ necessarily reached the constitutional question of the enactment's validity under this broad interpretation. "I can find no principle of federalism nor word of the Constitution that denies Congress power to determine that in order adequately to protect the right to equal utilization of state facilities, it is also appropriate to punisin other individuals-not state officers themselves and not acting in concert with state officers . . . ."41 Justice Brennan's view is that section 241 is a valid exercise of congressional enforcement power and that it reaches purely private acts violating fourteenth amendment riglits.

Justice Clark, in his opinion ${ }^{42}$ joined by Justices Black and Fortas, concurred in the Court's interpretation of section 241. However, he felt it necessary to express his views concerning the limits of congressional authority under the enforcenient section of the fourteenth amendment. "[T] here now can be no doubt that the specific language of $\S 5$ empowers Congress to enact laws punishing all conspiracies-with or without state action-that interfere with Fourteenth Amendment rights."43 Although Justice Clark only stated that private conspiracies may be reached ${ }^{44}$ while Justice Brennan indicated that the enforcement power extends to private individuals acting unilaterally, ${ }^{45}$ the two concurring opinions are in agreement that the state action rule no longer determines the limits of Congress's enforcement power. The opinions are indistinguishable in the sense that once the state action requirement has been obviated, there appears to be no basis in constitutional law for distinguishing between the activities of a private group taken pursuant to a common agreement and those of a private individual acting on his own. The criminal law frequently and usefully makes sucl a distinction. ${ }^{46}$ However, the purpose of the law of crimes is different from that of constitutional law. The former is concerned with deterring anti-social conduct, ${ }^{47}$ the latter with the defimition of the appropriate subjects and objects of governmental power. ${ }^{48}$ The distinction between acts done pursuant to an agreement and those done unilaterally is designed to aid the criminal law in the

$40 \mathrm{Id}$. at 776-77.

41 Id. at 784 .

42 Id. at 761 .

43 Id. at 762.

44 Ibid.

45 Id. at 784.

46 See, e.g., Clark \& Marshalt, Crmares $\$ \$ 9.00-.03$ (6th ed. 1958).

47 Id. $\$ 1.00$.

48 See, e.g., Heart of Atlanta Motel, Inc. v. United States, 379 U.S. 241 (1964); Nebbia v. New York, 291 U.S. 502 (1934); Hammer v. Dagenhart, 247 U.S. 251 (1918); Lochner v. New York, 198 U.S. 45 (1905); Civil Rights Cases, 109 U.S. 3 (1883). 
fulfillment of its purpose. ${ }^{49}$ Such a distinction would not aid in achieving the goals of constitutional law. Hence, it should not be made when the concern is the determination of the proper objects of congressional power. Once one determines that some forms of private action can be subjected to congressional control by the fourteenth amendment, it is necessary to say that all forms-group and unilateral-are subject to that same control. In effect, six Justices have come to the conclusion that the state action concept is no longer applicable to enforcement legislation.

Justice Brennan's and Clark's Guest opinions significantly expanded the limits of Congress's enforcement power without dealing with a difficult conceptual hurdle. The equal protection clause begins with the words "nor shall any State ...." Th0 This langnage, upon which the concept of state action is founded, raises the question whether there can be a legal right under the fourteenth amendment for Congress to enforce without state involvement in the infringing acts. Neither Justice Brennan nor Justice Clark discussed his views of the nature of legal rights.

Basically, there are two conceptions ${ }^{51}$ of legal rights, ${ }^{52}$ either of whicls Justices Brennan and Clark could have had in mind when they delivered their Guest opinions. The first of these conceptions, the idealistic view, conceives of rights as completely defined by a description ${ }^{63}$ of the content of the right. Under this conception, a right is defined without reference to the party or agency against wliose acts it is protected. ${ }^{54}$ That is, a right can be granted without imposing a duty on some other party to refrain from infringing upon it. For example, under the idealistic conception, the equal protection clause could be phrased in this manner: "Every person shall be accorded the equal protection of the laws." The right would be created by that phrase, but no protection against invasion would be provided. ${ }^{55}$ It miglit be necessary to specify "equal protection" with greater

49 Compare Dennis v. United States, 341 U.S. 494, 510-11 (1951), with Crark \& MARSHALL, op. cit. supra note $46, \S 1.00$.

50 See note 3 supra.

51 The two conceptions of the nature of a right here presented are not attributable to any particular writer. They represent the author's understanding of the ideas entertained by general categories of legal philosophers, of whon some of those cited in notes 54-59 infra are representative.

52 No reference to any specific right is intended whenever the term "legal right" or similar phraseology is used. Rather the term is meant to refer to equal protection and due process rights in an abstract sense; it includes whatever specific rights are embodied in those clauses, however they may be described. See note 11 supra.

53 See note 11 supra.

54 See 4 Pound, JURISprudence 56-71 (1959); RitchIE, Natural Rigrts 78-81 (1895).

55 Compare the dispute between Cardozo, C.J., and Andrews, J., in Palsgraf v. Long Island R.R., 248 N.Y. 339, 162 N.E. 99 (1928). 
precision by pointing out concrete examples, but that is merely further description of the right.. ${ }^{56}$ The adherents of this view would say of the equal protection clause, as it is actually written, that it grants the right to equal protection and that, in addition, the amendment protects that right against the actions of the states. ${ }^{57}$

The second conception of legal right which the justices have had in mind contemplates an operational definition of the right. This positivistic view requires, for a complete definition, not ouly a description of the content of the right but also a statement of the entity against whose actions the right is protected. ${ }^{58}$ It is not sufficient to say that everyone has the right to equal protection of the laws. More is required. A duty must also be imposed upon some party or agency to avoid abridging the right. Statements of both content and duty are necessary to grant the right. ${ }^{59}$ Without both the description and the provision of a duty, the definition is incomplete and the right does not exist for legal purposes. With respect to the equal protection clause, the proponents of this view would say that no right would be created if it were phrased: "Every person shall be accorded the equal protection of the laws." No person would be under a duty to abide the right. The right could only be created by a statement similar to the equal protection clause as it is actually written. Thus, positivists would say that the fourteenth annendment provides the right to be free from unequal treatment by the state. ${ }^{60}$

It is easy to see that the interpretation of congressional enforcement power adopted by Justices Brennan and Clark in the Guest case can be rationahzed if they conceived of equal protection rights in the idealistic

56 Compare RrTchIE, op. cit. supra note 54 , at 80.

57 The Court in the Civil Rights Cases, 109 U.S. 3 (1883), took this view of the nature of a fourteenth amendment right. The Court discussed the rights and protections granted by the fourteenth amendment as if they were separate and independent. There is continual reference both to the positive individual rights created by the amendment and to the protection from infringement by the states. The Court's discussion of the nature of fourteenth amendment rights, $i d$. at 17-18, further supports the inference that the Court followed an idealistic approach. The Court indicates that private interferences with the free exercise of fourteenth amendment rights constitute legal wrongs which are to be remedied presumably by resort to state laws. Such interferences could not be legal wrongs uuless they invaded legal rights. Apparently, then, the Civil Rights Court conceived of the fourteenth amendment as describing legal rights which everyone has against everyone else, and providing specific protection against infringement by the state. Compare 4 PoUND, op. cit. supra note 54, at 70.

58 Hoimeld; FundantentaI Legat Conceptions 36-50 (1964); Paton, Jurisprudence 249 (1964). See, e.g., Ross, ON Law and Justice 189-92 (1959); Salmond, JuRIsprudence 229-47 (11th ed. 1957).

59 Sarirond, op. cit. supra note 58, at 233.

60 This view was adopted by Justice Stewart in Umited States v. Guest, 383 U.S. 745, 755 (1966). "It is a commonplace that rights under the Equal Protection Clause itself arise only where there has been involvement of the State or of one acting under color of its authority." 
sense. Under that view of the nature of a right, the protection given by the amendment itself is independent of the grant of the right. The enforcement power given Congress by the fifth section of the amendment could certainly be seen as including the authority to expand the class of groups, agencies, and individuals against whom the rights described by the equal protection clause will be protected. Indeed, such power seems almost a necessary result of the ideahistic conception of legal right. If Congress has power to enforce the provisions of the amendment, and if the amendment provides rights good against the whole world, it is only logical that Congress has the authority to impose duties where the amendment has omitted them.

It is not so easy to see that Justices Brennan's and Clark's expansion of the enforcement power can be rationalized if they subscribe to the positivistic conception. Since the fourteenth amendment says that no state shall deny equal protection, positivists would say that no fourteenth amendinent right arises absent state action. Without state involvement in the depriving activity, there would be no right for Congress to enforce. However, the enforcement section of the fourteenth amendinent can be viewed as a grant to Congress of the power to create new rights by defining new classes against whose actions the rights described in the first section are protected. At least, such a view would not be inconsistent with the meaning of the word "enforce." The Court's recent holding in Katzenbach v. Morgan ${ }^{61}$ lends credence to this interpretation of the enforcement power. In that case, the Court granted Congress the power to expand the descriptive aspect of fourteenth amendinent rights. The power to create new positivistic rights would simply be the power to expand the duty aspect of those rights, however they are described. If Congress has the power to expand the descriptive aspect of the rights granted by the fourteenth amendinent, it is only logical that it should also have the power to expand the duty aspect.

A majority of the justices has come to the conclusion that state action in the deprivation of fourteenth amendment rights is no longer a condition precedent to the application of enforcement legislation. This conclusion is not dependent upon the adoption of a particular view of the nature of fourteenth amendment rights. Hence, when judges in the future apply enforcement legislation, they need not be worried by philosophical micities. Different results are not dictated by different plilosophies of law.

The Guest case, on its facts, dealt only with congressional enforcement of the equal protection clause. But the language of Justices Brennan and

61384 U.S. 641 (1966). This case is discussed in detail in text accompanying notes 75-113 infra. 
Clark is equally applicable to enforcement of any of the clauses in the first section. Justice Clark spoke of the enforcement power in general terms; his language is not restricted to the equal protection clause. ${ }^{62}$ Justice Brennan said that "the reach of $\S 241$ should not vary with the particular constitutional provision that is the source of the right." the state action rule were to remain applicable to due process rights while it was abrogated with respect to equal protection rights, a result contrary to that called for by Justice Brennan would be achieved. Thus, it appears that Justice Brennan was right-the requirement of the Civil Rights Cases that there must be state involvement in actions adverse to fourteenth amendment rights prior to application of enforcement legislation was implicitly overruled ${ }^{64}$ by the separate opinions in which six justices concurred. $^{65}$

\section{The Fourteenth Amendment and Affirmative Obligations}

To this point, consideration of congressional powers has been limited to Congress's powers to prohibit actions and to provide punishments for their commission. The question remains whether Congress can require that states and individuals take affirmative action to ensure that others are accorded equal protection and due process of law.

There are several instances in which the Supreme Court has held that states are required to take affirmative action to ensure that all within their jurisdiction are accorded equal protection and due process. The reapportionment cases, for example, required states to re-designate the districts of their state legislatures so that all persons in the state receive substantially equal representation. ${ }^{66}$ The right-to-counsel cases held that

62 United States v. Guest, 383 U.S. 745, 762 (1966).

63 Id. at 780.

64 Id. at 782-83.

65 The Guest decision does not bring all private action within the purview of the enforcement power. Justices Brennan's and Clark's opinions only apply federal legislation to private infringements of rights described by the fourteenth amendment. In many instances, fourteenth amendment rights are described in terms of some state association with a private individual. Thus, the equal protection right which the defendants in Guest allegedly infringed was the right to equal utilization of facilities provided by the state. Because of the Court's former requirement that there be state association with the acts infringing fourteenth amendment rights, state-owned facilities are distinguished from privately-owned facilities. Whether the description of the right will be expanded to include facilities not owned by the state remains to be seen. It should be noted, however, that Katzenbach v. Morgan, 384 U.S. 641 (1966), gives Congress power concurrent with that of the Court to expand the description of fourteenth amendment rights. See text accompanying notes 75-113 infra.

80 E.g., Burns v. Richardson, 384 U.S. 73 (1966); Fortson v. Dorsey, 379 U.S. 433 (1965); Roman v. Sincock, 377 U.S. 695 (1964); Reynolds v. Sims, 377 U.S. 533 (1964). "[T]he Court below acted ... proper[ly] . . . in ordering its own temporary reapportionment plan into effect . . . " Reynolds v. Sims, supra at 586 . 
states must provide a defense attorney for an indigent defendant in a felony prosecution. ${ }^{67}$ In Griffin v. County School Board, ${ }^{08}$ the Court required the state to tax the inhabitants of a Virginia county and use the money to provide unsegregated public schools. There are other instances, ${ }^{60}$ all of which serve to indicate that the fourteenth amendment, in and of itself, can impose affirmative obligations on the states.

The Court has always held that congressional requirements imposed under the enforcement power could be as extensive as those of the amendment itself. ${ }^{70}$ Moreover, it would be difficult to conclude that congressional legislation requiring affirmative action in those cases in which the equal protection and due process clauses themselves require it. was not "appropriate legislation" to enforce those clauses.

The question of whether Congress should be able to impose affirmative obligations upon individuals and states in instances in which it has not previously been held by the courts that the fourteenth amendment itself imposes them should be answered in the affirmative. A contrary conclusion would amount to a holding that, with respect to the imposition of affirmative steps, congressional power under the amendinent is no greater than is that of the judiciary. ${ }^{71}$ Such a result was not contemplated by the framers of the amendment. At the time the amendinent was adopted, the prevailing view was that congressional powers were increased. ${ }^{72}$

Other relevant considerations also support this position. The words "appropriate legislation" import the necessary and proper clause into the fifth section of the fourteenth amendment. ${ }^{73}$ Hence, the appropriate test to be applied to exercises of congressional power under the fourteenth amendment is that articulated by Chief Justice Marshall in $\mathrm{McCul}$ -

${ }^{67}$ E.g., Douglas v. California, 372 U.S. 353 (1963); Gideon v. Wainwright, 372 U.S. 335 (1963).

88377 U.S. 218 (1964).

00 In Burton v. Wilmington Parking Authority, 365 U.S. 715, 725-26 (1961), the Court indicated that the state should have required its lessee to covenant against discriminatory practices. In Griffin v. Tlinois, 351 U.S. 12 (1956), the Court held that states were required to provide indigent criminal defendants with a free transcript of trial proceedings for purposes of appeal.

70 The Civil Rights Cases, 109 U.S. 3, 13 (1883), held that the extent of the fourteenth amendment's prohihitions were the definition of the extent of congressional power under that amendment.

71 The powers of Congress and of the Court were both expanded by the adoption of the amendment, at the expense of state powers. Congress's powers were expanded by the inelusion of the enforcement section, those of the Court by virtue of its function as the principal interpreter of constitutional provisions.

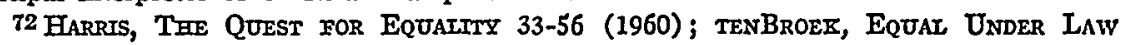
203-23 (1965). Frantz, Congressional Power to Enforce the Fourteenth Amendment Against Private Acts, 73 Yare L.J. 1353, 1356-57 (1964).

78 E.g., Katzenbach v. Morgan, 384 U.S. 641, 651 (1966); TENBroEK, op. cit. supra note 72, at 205-07. 
loch v. Maryland..$^{74}$ If the requirement of affirmative action which Congress uses to ensure that equal protection and due process are accorded every person is plainly adapted to that end and is not expressly prohibited by the Constitution, the requirement should receive judicial approval.

To recapitulate, United States v. Guest was the culmination of a long trend which removed the state action limitation from congressional enforcement legislation enacted under the fourteenth amendment. Moreover, in using its enforcement power, Congress need not limit itself to prohibiting actions; it can, in accordance with the test of the necessary and proper clause, require that affirmative actions be taken by states and individuals if such requirements are adapted to the goal of protecting equal protection and due process rights.

II

\section{Morgan AND STANDARDS OF REVIEW}

Guest considered only one of the two questions which arises in an interpretation of congressional enforcement powers. It dealt with the problems of defining the groups or agencies against which fourteenth amendment rights are protected. The other problem is the specification of those amorphously defined rights. Katzenbach v. Morgan ${ }^{75}$ considered this second question and held that, if Congress made a reasonable judgment that certain actions violate the equal protection clause, that judgment would be honored by the courts. ${ }^{78}$

\section{A. Congressional Interpretation of the Equal Protection Clause}

The opinion of the Court gave detailed treatment to the constitutionality of section 4(e) of the Voting Rights Act of $1965 .{ }^{77}$ That act, in pertinent part, provided that hiteracy tests could not be used to deny the right to vote to any person who could prove that he had completed the sixth grade in an American flag school in which the predominant classroom language was other than Enghish. The State of New York had both statutory ${ }^{78}$ and constitutional ${ }^{79}$ provisions requiring new voters to demonstrate an ability to read and write English. These New York provisions had the

7417 U.S. (4 Wheat.) 316 (1819). "Let the end be legitimate, let it be within the scope of the constitution, and all means which are appropriate, which are plainly adapted to that end, which are not prohibited, but consist with the letter and spirit of the constitution, are constitutional." Id. at 421.

75384 U.S. 641 (1966).

$76 \mathrm{Id}$. at $653-57$.

7779 Stat. 437 (1965), 42 U.S.C. \& 1973b(e) (Supp. I, 1965).

78 N.Y. Election Law $\$$ 150, 168.

79 N.Y. Const. art. II, $\S 1$. 
effect of disenfranchising thousands of American citizens who had been part of the influx of Puerto Ricans into New York. Many Puerto Rican New Yorkers were literate in Spanish but not in English, because Spanish is the principal language of instruction in Puerto Rican public schools. Section 4(e) would remove, for them, New York's English literacy prerequisite to the right to vote. The trial court found that section $4(\mathrm{e})$ violated the tenth amendment ${ }^{80}$ because Congress did not have the power to enact it. ${ }^{81}$

The Court, through Justice Brennan, began by stating ${ }^{82}$ that the limits of congressional powers to enforce the equal protection clause were to be measured by the test whicli was announced by Chief Justice Marshall in $M c C u l l o c h$ v. Maryland. ${ }^{83}$ This led the Morgan Court to consider three questions: (1) May the enactment be regarded as an enforcement of the equal protection clause; (2) is the enactment "plainly adapted to that end"; and (3) is the enactment not prohibited by "the letter and spirit of the constitution"? 84

The Court answered the first question in the affirmative on two grounds. First, Congress had expressly declared that section 4(e) was enacted to secure fourteenth amendment rights for the persons in favor of whom the statute was adopted. ${ }^{85}$ Second, the statute was viewed as a measure designed to secure for Puerto Ricans residing in New York nondiscriminatory treatment by the government-with respect to both voting qualifications and provision or administration of governmental services. ${ }^{80}$ The Court's reliance upon the congressional declaration is worthy of note. Implicit in that reliance is the Court's acceptance of the congressional determination that demial of the right to vote on the basis of illiteracy in English is a denial of equal protection. This indicates that Congress might have some authority to interpret the equal protection clause. The extent of that authority, however, was not immediately considered. ${ }^{87}$

The question of whether the act was plainly adapted to the end was considered from two points of view. First, the Court looked at the statute as being enacted for purposes of securing to the Puerto Rican minority the means by which they might better secure for themselves "perfect

80 "The powers not delegated to the United States by the Constitution, nor prohibited by it to the States, are reserved to the States respectively, or to the people."

81 Morgan v. Katzenbach, 247 F. Supp. 196, 200 (S.D.N.Y. 1965).

82 Katzenbach v. Morgan, 384 U.S. 641, 651 (1966).

8317 U.S. (4 Wheat.) 316,421 (1819). See note 74 supra.

84384 U.S. at 651 .

85 Id. at 652 .

86 Ibid.

87 This point is also raised in another part of the opinion, where the Court considered it in detail. For this reason, detailed discussion is also postponed here. See text accompanying notes 92-96 infra. 
equality of civil rights and equal protection of the laws."88 State interests and competing individual interests, both of which Congress might have considered when it was contemplating the statute, were mentioned. The Court then held that the balancing of such interests is a legislative function. A court may not review sucl a congressional weighing of interests: "It is enough that we be able to perceive a basis upon which the Congress might resolve the conflict as it did." 89 In Morgan, the Court found that there was sucl a basis. ${ }^{90}$ Essentially, the question presented by the second step in the Court's review was answered in the affirmative by finding some reasonable foundation for the result which Congress reached in balancing the interests of the states against individual interests. Remembering that this standard of review was announced under a view of section 4 (e) defined by a judicially conceived congressional purpose, it is easily seen that the position assumed by the Court was not novel. ${ }^{.1}$

Under its second view of section $4(\mathrm{e})$, the Court took an entirely different position from that which it had heretofore assumed. The Court viewed the statute as being aimed at the elimination of an invidious discrimination. ${ }^{92}$ It then declared that such a statute is valid if the Court is able to perceive a basis for Congress's judgment that the state activity, which it is the object of the statute to prohibit, constitutes an invidious discrimination..$^{83}$ This approach leaves to Congress the power under section five of the fourteenth amendment to make reasonable judgments in the definition of state activities proscribed by the equal protection clause. This is indeed a significant expansion of congressional enforcement powers. For eighty-three years, the Court had imposed a much more stringent standard of review upon congressional legislation enacted under the fourteenth amendment. ${ }^{94}$ Formerly, the Court determined for itself that the activities prohibited by fourteenth amendment legislation were actually condemned by the amendment ${ }^{95}$ before upholding the exercise

88384 U.S. at 653 .

89 Ibid.

90 Ibid.

91 The Court has frequently held that the balancing of interests is a function which legislatures are peculiarly competent to fulfill. If the result of the process has a reasonable foundation, the Court will not interfere. E.g., Ferguson v. Skrupa, 372 U.S. 726, 730 (1963); Williamson v. Lee Optical, 348 U.S. 483, 487 (1955); Railway Express Agency v. New York, 336 U.S. 106, 109-10 (1949); Lincohi Fed. Labor Union v. Northwestern Iron \& Metal Co., 335 U.S. 525, 536-37 (1949); Olsen v. Nebraska, 313 U.S. 236, 246 (1941); West Coast Hotel Co. v. Parrish, 300 U.S. 379, 398-99 (1937).

82384 U.S. at 653-54.

83 Id. at 656 .

94 Perhaps the best example of this more stringent standard is the Civil Rights Cases, 109 U.S. 3, 14 (1883).

95 See, e.g., Hodges v. United States, 203 U.S. 1, 14 (1906) ; United States v. Harris, 106 U.S. 629, 638 (1882); Ex Parte Virginia, 100 U.S. 339, 345 (1879). 
of the enforcement power. ${ }^{96}$ Morgan shifted the focus of the Court's inquiry. The Court will now look only at the reasonableness of Congress's finding that the activity proscribed is an invidious discrimination to determine the validity vel non of the statute.

The question of whether the means which Congress selected were prohibited by the Constitution did not present any difficulty for the Court. The appellees, in challenging section 4(e), contended that the section itself worked an invidious discrimination in that it was not applicable to people educated in schools beyond the territorial jurisdiction of the United States." The Court simply noted that "reform may take one step at a time," applicability of the measure. ${ }^{99}$ Again a reasonableness test was applied. If the Court could conceive a reasonable basis for Congress's himitation on the scope of apphicability of a reform measure, the hmitation would not be susceptible to a constitutional attack. ${ }^{100}$

\section{B. Standard of Judicial Review}

Before considering the potential effects of the Morgan decision, it will be useful to resolve an apparent ambiguity in the decision regarding the exact definition of the scope of review. The standard stated by the Court fluctuates, depending upon the placement of the burden of proof and the weight of the burden imposed. It appears that the Court imposed the burden of proving unreasonableness upon the party attacking the statute. It is true that the Court said several times ${ }^{101}$ that it must be able to perceive a basis upon which Congress might have predicated its judgment. In reality, each time it was nominally required that there be perception of a basis, the Court conceived the appropriate foundation. It is said that Congress might have considered these factors ${ }^{102}$ or might have balanced those interests. ${ }^{103}$ The Court did not require that it be shown or even indicated that Congress actually did the suggested considering or balancing. In effect, this willingness to conceive a rational basis for the statute under attack establishes a presumption of validity in Congress's favor. Such a presumption, of course, places the burden of proving the absence of a reasonable basis upon the party attacking the statute's validity. Because the extent of the burden put upon the challenger of a

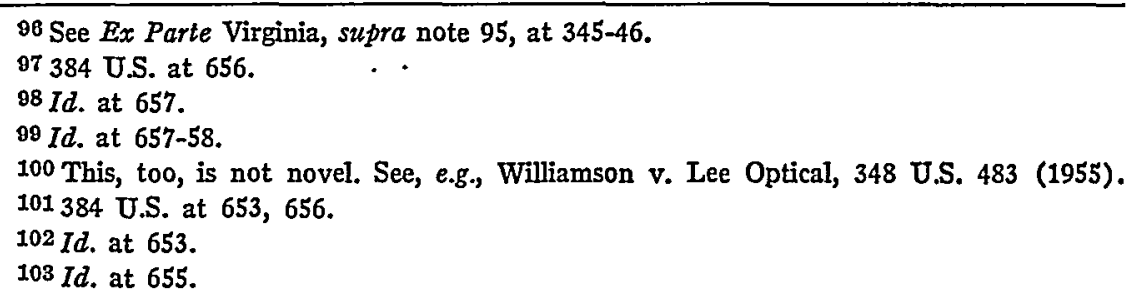


statute is not clear from the opinion, that determination will have to await further cases.

The implications of the standard of judicial review used in Morgan are broad. Any reasonable reading of the opinion leads at least to this result: Congress can displace any state regulation whicl utilizes a distinction between classes of people by making a reasonable judgment that the distinction is an invidious discrimination. But the Morgan doctrine is not destined to be himited to equal protection legislation. There is little reason to believe that a different standard would be applied to statutes designed to enforce the due process clause. When the Court said that the $M c C u l l o c h$ v. Maryland standard was applicable, ${ }^{104}$ it was speaking of legislation enacted under section five of the fourteenth amendment, not of legislation under that section which was passed only for purposes of enforcing the equal protection clause. ${ }^{105}$ Only when the Court turned its attention to the specific case at hand did it limit its reasoning to equal protection legislation. ${ }^{106}$ Hence, it appears that Congress need only make reasonable judgments that specified state practices work an invidious discrimination or deny due process to support its action in displacing and superseding those state practices.

The specific implications of the Morgan interpretation of the enforcement powers of Congress under the fourteenth amendment are clear. In any area in whicl the Supreme Court has applied the equal protection or due process clause against actions taken by the states, Congress can nationalize enforcement of individual rights. All restrictions on the right to vote whicl Congress reasonably finds to be invidious can be removed. ${ }^{107}$ The actions which a state may take with respect to criminal defendants ${ }^{108}$ may be subjected, in large measure, to Congress's jurisdiction. Congress may regulate, to a great extent, the state's educational system, ${ }^{109}$ its provision of recreational facilities, ${ }^{110}$ and the scope of authority accorded law enforcement officers. ${ }^{111}$ Moreover, Congress can declare those clauses applicable in areas of state practice which the Court has not yet con-

$104 I d$. at 650 .

$105 \mathrm{Id}$. at 651 .

106 Id. at 652 .

107 See, e.g., Reynolds v. Sims, 377 U.S. 533 (1964); Baker v. Carr, 369 U.S. 186 (1962); Nixon v. Condon, 286 U.S. 73 (1932); Nixon v. Herndon, 273 U.S. 536 (1927).

108 See, e.g., Rideau v. Louisiana, 373 U.S. 723 (1963) (pre-trial publicity); Robinson

v. California, 370 U.S. 660 (1962) (cruel and unusual punishment); Spano v. New York, 360

U.S. 315 (1959) (involuntary confessions).

109 See, e.g., Brown v. Board of Education, 347 U.S. 483 (1954); Griffin v. County School Bd., 377 U.S. 218 (1964).

110 See, e.g., Evans v. Newton, 382 U.S. 296 (1966); Griffin v. Maryland, 378 U.S. 130 (1964).

111 See, e.g., Aguilar v. Texas, 378 U.S. 108 (1964); Mapp v. Ohio, 367 U.S. 643 (1961). 
sidered, and even in situations where they have been held inapplicable. ${ }^{112}$ These powers are limited only by the requirement that Congress must make a reasonable judgment that the state practices involved violated the due process or equal protection clauses. ${ }^{113}$

\section{III}

\section{Guest-Morgan EXPANSION OF FEDERAL POWER}

Either the Guest or the Morgan decision, taken alone, would be a revolutionary interpretation of congressional enforcement powers under the fourteenth amendment. The first removes all himitations upon the groups or persons to which enforcement legislation can be applied, given the finding that a constitutional right is involved. ${ }^{114}$ The second allows Congress the power to make reasonable specifications of the rights defined generally by the equal protection and due process clauses. ${ }^{115}$ When these two expansions of federal legislative power are considered together, congressional authority under the fourteenth amendment is extended further than might appear from their separate consideration. These increased powers, because of their complementary nature, are cumulative. Thus, in reliance upon Morgan, Congress can formulate a reasonable judgment that specified state activities contravene either the due process or equal protection clause. Then, in reliance upon Guest, it can prohibit both states and private groups or individuals from committing those acts. Furthermore, Congress could make a reasonable determination that an existing state of affairs is contrary to the requirements of the fourteenth amendinent, and then, consistent with the McCulloch test which Morgan applied to Congress's enforcement powers, require that states or individuals take specified, affirmative steps to rectify the situation. ${ }^{116}$ If the affirmative action so required by Congress is reasonably adapted to the correction of the situation which Congress has reasonably found to violate the equal protection or due process clause, the requirement is a valid exercise of Congress's enforcement powers, unless the means chosen violate some express limitation upon those powers. ${ }^{117}$

The extent of the Morgan and Guest expansions of congressional

112 See note 119 infra.

113 The greatest increase in federal power would come through the due process clause, since it incorporates much of the Bill of Rights. For an indication that Congress can enforce the provisions of the first nine amendments against the states through the exercise of its enforcement power, see Monroe v. Pape, 365 U.S. 167 (1961) (federal civil cause of action can be provided for unreasonable search and seizure).

114 See text accompanying notes 39-61 supra.

115 See text accompanying notes 92-96 supra.

110 See text accompanying notes $66-74,83$ supra.

117 See text accompanying notes 97-100 supra. 
fourteenth amendment powers can perhaps be best illustrated by pointing out the limitations upon those powers. The means available for effectuation of congressional goals, and the subject matter concerning which Congress can legislate, are limited by other constitutional provisions and by the separation of judicial and legislative powers in the federal government. A thorough definition of those limitations necessarily delimits a residuum of ends and neans-all of which are anienable to congressional enforcenient legislation.

\section{A. Limitations on Congressional Enforcement Power Imposed by the Doctrine of Separation of Powers}

The first limitation on congressional enforcenient power is stated in the Morgan opmion itself: Congres cannot "restrict, abrogate, or dilute" the guarantees of the fourteenth amendment. ${ }^{118}$ Thus, Congress cannot overrule a Court decision which holds that the amendment prohibits a specified activity, but can overrule one which decides that a challenged discrimination is not invidious. Indeed, Congress did precisely the latter when it enacted section 4(e) of the Voting Rights Act of 1965, which Morgan upheld. ${ }^{119}$ Moreover, it seenis that if Congress should determine that a particular action of the states is not in derogation of rights protected by the aniendment, the Court, when reviewing the statute, would feel free to make its own determination of the extent of the alleged rights involved. Consideration of what the Court must do in such a situation to ensure that Congress does not "restrict, abrogate, or dilute" the fourteenth amendment guarantees indicates that this is the approach the Court would take. The Court must determine for itself the extent of the protection given by the fourteenth amendment in the situation to which Congress has turned its attention. If that determination yields a result contrary to that arrived at by Congress, the congressional declaration must fall, since it would be a restriction, abrogation, or dilution. Hence, it appears that congressional enforcement powers under the fourteenth amendment include the authority reasonably to determine that specified activities or conditions contravene the equal protection or due process clause. Congress cannot, however, without stringent Court review, make any determination, reasonable

118 Katzenbach v. Morgan, 384 U.S. 641, 651 n.10 (1966).

119 In Lassiter v. Northampton County Bd. of Elections, 360 U.S. 45 (1959), the Court held it within a state's power to require satisfactory completion of a literacy test, as long as the test was applied to all prospective voters irrespective of race or color and in such a manner that it discriminated only on the basis of literacy. Id. at 50-53. In effect, this is a statement that discrimination against those not literate in the English language is not invidious. Section $4(\mathrm{e})$ is a legislative declaration that discrimination against Puerto Ricans literate in Spanish, but not in English, is invidious. 
or otherwise, that specified activities or conditions do not contravene those clauses.

\section{B. Limitations on Congressional Enforcement Power Imposed by the Constitution}

The other limitation on congressional enforcement power inheres in the difference between the scope of congressional powers and the limits upon them. By the Morgan decision, the Court allows Congress reasonably to say: This state activity is prohibited by the equal protection (or due process) clause. The power granted is simply the power to express an opinion about the scope of congressional authority under the enforcement section. If the opinion is reasonable, it will be accepted by the Court. But when the Court is presented with an allegation that the statute which Congress has enacted to enforce its reasonable judgment infringes upon some other individual right protected by another constitutional provision, the judges will not abrogate their responsibility to determine the existence and extent of that other right. Failure to accept this responsibihty would amount to a renunciation of the traditional relationship between the Congress and the Court. Since Marbury v. Madison, ${ }^{120}$ the Court has been the final arbiter when questions arise involving the extent of congressional power. One of the Court's most important functions has long been to protect minority rights against the tyranny of the majority. A major means by which the Court has fulfilled this function has been to measure all legislative enactments against the specific prohibitions of the Constitution. ${ }^{121}$ There is no reason to beheve that the Court is on the verge of abandoning that important function or the means by which it is performed. Indeed, the Morgan opinion indicates just the opposite.

In Morgan it was asserted that the questioned legislation conflicted with the due process clause of the fifth amendment. ${ }^{122}$ The Court made its own determination of the extent to which that clause limited Congress's powers to enact reform legislation. ${ }^{123}$ Regardless of Congress's reasonable judgment that control of the application of literacy tests was necessary to eliminate one invidious discrimination, the statute would have been

1205 U.S. (1 Cranch) 137 (1803).

121 See, e.g., Gideon v. Wainwright, 372 U.S. 335 (1963) (right to counsel); Watkins v. United States, 354 U.S. 178 (1957) (right to know standard of criminality); Brown v. Board of Education, 347 U.S. 483 (1954) (right to be free from invidious discriminations); Lovell v. City of Griffin, 303 U.S. 444 (1938) (freedom of the press); Schenck v. United States, 249 U.S. 47 (1919) (right to freedom of speech); Weeks v. United States, 232 U.S. 383 (1914) (right to be free from unreasonable searches and seizures); Yick Wo v. Hopkins, 118 U.S. 356 (1886) (right to be free from invidious discriminations).

122384 U.S. at 656.

${ }^{123}$ Id. at $656-58$. 
declared unconstitutional had it been determined that it worked another such discrimination. ${ }^{124}$

These limitations only protect individuals against overzealous congressional action. They do not ensure continuation of the state's jurisdictional domain over the various types of subject matters which might conceivably be brought within the ambit of the fourteenth amendment by a congressional exercise of reasonable judgment. ${ }^{125}$ Congress could require, for example, that the Federal Rules of Civil Procedure be used in all state courts by making a reasonable judgment that this was necessary to enforce the due process clause. Congress could, by making a similar determination, supplant all state penal codes. To enforce the equal protection clause, federal law enforcement agencies could be used to replace their state counterparts. ${ }^{126}$ Reflection leads one to the conclusion that, under these expanded fourteenth amendment powers, Congress could, for all practical purposes, abohish the states.

\section{The Extra-Constitutional Limitation}

One factor, however, mitigates the likelihood that Congress will substantially reduce the vitality of the states as jurisdictional entities. This is the limitation on the exercise of the enforcement power inherent in Congress's representative nature. ${ }^{127}$ Congressmen represent the local interests which form their constituency as well as the nation as a whole. This double representation results in three factors exerting substantial influence upon a congressional decision on the question whether, in any given case, federal power should be exercised. The first factor is the competition of the local interests each congressman represents. Some will demand federal action, others will urge inaction. How a congressman votes on an issue depends, to some extent, upon his conception of the way

124 See $i d$. at 657 , where the Court refers to the "principle that calls for the closest scrutiny of distinctions in laws denying fundamental rights . ..."

125 There are no affirmative assurances in the Constitution that state governmental powers must be preserved. The tenth amendment, which is the only provision that affirms the existence of powers in the states, is merely a residuary clause. It only reserves those powers to the states which are neither delegated to the federal government nor prohibited to the states by the Constitution. United States v. Darby, 312 U.S. 100, 123-24 (1941); Larche v. Hannah, 177 F. Supp. 816, 821 (W.D. La. 1959), rev'd on other grounds, 363 U.S. 420 (1960).

120 Such enactments would not raise a problem under the rule announced in Erie R.R. v. Tompkins, 304 U.S. 64 (1938). That case said that the federal government could supervise the judicial action of the states only pursuant to constitutional authorization. Id. at 79 . If failure to use the Federal Rules of Civil Procedure amounts to a denial of due processand formulation of a reasonable judgment by Congress that such is the case would be conclusive with respect to that issue-the enforcement section of the fourteenth amendment is sufficient constitutional authorization.

127 Gibbons v. Ogden, 22 U.S. (9 Wheat.) 1, 197 (1824); Cox, Foreword: Constitutional Adjudication and the Promotion of Human Rights, 80 HARv. L. REv. 91, 119 (1966). 
interest groups in his electorate want him to vote. The second factor is the congressman's rational consideration of which level of government is best suited to solve a particular problem. Some problems are more easily and adequately solved by local regulation than by national legislation. On the other hand, there are some issues which only the national government can resolve. The third factor is the wide-spread commitment among Americans to the federal form of government. This emotional attachment to the present system includes a bias in favor of local government as the most appropriate agency to perform the bulk of governmental tasks. The combined influence of these three factors leaves hittle chance that a statute truly offensive to the continued vitality of the states will be adopted.

\section{CONCLUSIONS}

United States v. Guest and Katzenbach v. Morgan announced a new and significant expansion of congressional powers at the expense of what traditionally had been thought to be the exclusive preserve of the states. Guest abolished the requirement that action attributable to the state must be found as a condition precedent to the application of federal statutes which implement the fourteenth amendment. The abrogation of this application of the concept of state action was predictable in view of the constant erosion of the doctrine found in the civil rights crimes cases ${ }^{128}$ and the failure of some of the states to provide adequate protections for the exercise of equal protection and due process rights. Morgan established the right of Congress to interpret the equal protection and due process clauses. When the national legislature makes a reasonable judgment that specified activities violate those clauses, the Court will respect the congressional decision. This liberalization of the Court's standard of review for fourteenth amendment legislation was also foreseeable. Recent attacks upon the Court for its activism increased the likelihood that it would allow Congress to assume a role of leadership in the federal government's part in the struggle for equal and meaningful civil rights.

The limitations upon congressional powers under these decisions are those imposed by the Constitution itself and by the Court's assumption of its appropriate function as the supreme arbiter of disputes over the extent of congressional power. An additional limitation is found in the representative nature of Congress.

The propriety of these decisions should not be questioned. The Morgan decision merely gives to an elected body the powers which had formerly been exercised only by the judicial branch of the government. Interpreta-

128 E.g., United States v. Price, 383 U.S. 787 (1966); Screws v. United States, 325 U.S. 91 (1945). 
tion of the equal protection and due process clauses is largely a matter of making value judgments. Consistent with democratic theory, that function is best performed by the most representative of the branches of the government-the legislature. The decision is not, however, an abrogation by the Court of its traditional function in interpreting those clauses. There is no hint in Morgan that the Court will discontinue its role in finding that the clauses proscribe challenged state practices in appropriate cases. Nor is the Court abandoning its function of protecting minority rights from the will of the majority-Congress is denied the power to restrict or dilute the rights guaranteed by the amendment.

For one hundred years some states have demonstrated an unrelenting intransigence toward working for a full realization of the rights and human relationships embodied in the equal protection and due process clauses. What the states have been unable or unwilling to do, Congress might be able to achieve. It has been granted the opportunity by Guest and Morgan. 